\title{
Apocalipses e catástrofes: o lugar da distopia em narrativas contemporâneas da literatura e do cinema angolanos ${ }^{1}$
}

Carmen Lucia Tindó Secco ${ }^{a}$ (D)

${ }^{1}$ O presente artigo faz parte de nosso projeto atual de pesquisa que é apoiado pela Fundação Carlos Chagas Filho de

Amparo à Pesquisa do Estado

do Rio de Janeiro (FAPERJ) -

Programa Cientista do Nosso

Estado - e pelo Conselho

Nacional de Desenvolvimento

Científico e Tecnológico

(CNPq).

\begin{abstract}
RESUMO
$O$ artigo almeja refletir acerca de temporalidades e tempos distópicos presentes em narrativas contemporâneas de Angola, tanto no âmbito da literatura como do cinema. Com base nos romances O desejo de Kianda (1995) e O quase fim do mundo (2008), de Pepetela, e no filme Ar condicionado (2020), do cineasta Fradique (Mário Bastos) e do produtor Jorge Cohen, pretende-se efetuar um levantamento de representações alegóricas, investigando e discutindo seus respectivos significados e o lugar da crítica e da resistência em narrativas consideradas distópicas.
\end{abstract}

Palavras-chave: Angola. Literatura. Cinema. Distopia. Resistência. 
A floresta está viva. Só vai morrer se os brancos insistirem em destruí-la. Se conseguirem, os rios vão desaparecer debaixo da terra, o chão vai se desfazer, as árvores vão murchar e as pedras vão rachar no calor. A terra ressecada ficará vazia e silenciosa. Os espíritos xapiri, que descem das montanhas para brincar na floresta em seus espelhos, fugirão para longe. Seus pais, os xamãs, não poderão mais chamá-los para nos proteger. Não serão capazes de espantar as fumaças de epidemias que nos devoram. Não conseguirão mais conter os seres maléficos que transformarão a floresta num caos. Então morreremos um atrás do outro, tanto os brancos quanto nós. Todos os xamãs vão acabar morrendo. Quando não houver mais nenhum deles vivo para sustentar o céu, ele vai desabar. (KOPENAWA, 2015)

Assim como Davi Kopenawa adverte para o risco dos desmatamentos florestais, para o surto de previsíveis epidemias, pressagiando a "queda do céu", diversos escritores contemporâneos ficcionalizam desastres ambientais, guerras, ataques terroristas, violências - catástrofes anunciadoras de tempos sombrios que estão a ameaçar o meio ambiente, os animais, as sociedades, a humanidade.

O escritor angolano Pepetela, no romance $O$ quase fim do mundo (2008), cria uma alegórica representação do final dos tempos. Em sua narrativa, é do céu que desabam estranhos sinais sobre a Terra, deixando-a praticamente deserta, com pouquíssimos sobreviventes que, em meio à solidão, à perplexidade, se perguntam, atônitos, se teria sido um raio, uma bomba ou um castigo celeste.

José Eduardo Agualusa é outro autor, igualmente angolano, que, em seu romance Os outros e os vivos (2020), escrito em 2019, tem como cenário de sua narrativa a Ilha de Moçambique, lugar onde transcorre um festival literário do qual participam 30 escritores africanos. De repente, desponta um assustador temporal que devasta tudo, tornando as personagens, durante sete dias, prisioneiras, isoladas e sem internet naquele espaço insular ao norte moçambicano.

A presença de narrativas distópicas verifica-se, de modo recorrente, não apenas em criações artísticas atuais do século XXI, mas também em obras publicadas no final do século 
XIX, nas primeiras décadas do século XX e, principalmente, a partir de 1950, momento em que o mundo começa a vivenciar uma época de incertezas decorrente, em grande parte, do capitalismo neoliberal.

Neste ensaio, discutiremos o lugar da distopia em obras angolanas da literatura e do cinema, investigando em que medida a imaginação distópica ocupa espaços antes preenchidos pelas utopias e, contemporaneamente, não mais se opõe a estas, entrelaçando-se a estilhaços utópicos que resistem aos novos tempos.

Conceber distopia apenas como contrário de utopia gera leituras maniqueístas, reducionistas e pessimistas da história, o que, atualmente, vem sendo questionado em razão de as fronteiras de vários saberes se interpenetrarem:

[...] longe de pensar a distopia como uma negação ou como uma antítese da utopia - um topos localizado exclusivamente no futuro -, partimos da premissa de que a distopia se apresenta como uma espécie de embaralhamento, uma fusão de diferentes temporalidades. Assim, enquanto a utopia era vista como um lugar no futuro, pensamos a distopia como um deslugar inscrito, acentuadamente, num determinado tipo de presente. (BENTIVOGLIO; CUNHA; BRITO, 2017, p. 8).

Entre teóricos da distopia contemporânea como, por exemplo, Booker (1994), existe o entendimento de que o modo de pensar distópico deve atuar não contra formas utópicas de imaginar o mundo, mas, sim, concorrer para reflexões acerca de pesadelos iminentes, catástrofes, de forma a resguardar nesgas de esperanças que possam vir a preencher lacunas do presente e vazios futuros.

O conceito de retrotopia, criado por Zygmunt Bauman, segue orientação parecida, pois surge com intuito de combater o medo distópico dominante em muitas situações da contemporaneidade, buscando "visões instaladas num passado perdido/roubado/abandonado, mas que não morreu [...]" (BAUMAN, 2017, p. 10). Segundo o teórico, a retrotopia implica um regresso ao outrora, à cata de resíduos capazes de instigar uma ideia, mesmo que tênue e improvável, de porvir.

Nossa intenção, concebendo a distopia como "topos privilegiado para compreender as representações do imaginário social na chamada pós-modernidade" (BENTIVOGLIO; 
CUNHA; BRITO, 2017, p. 9), é verificar se, nos romances e filme selecionados para análise, persistem vestígios utópicos em meio à predominância de contextos distópicos.

Em O quase fim do mundo, a alegórica estratégia romanesca engendrada por Pepetela provoca espanto e choque nos leitores, que, assim como os personagens sobreviventes, de imediato não entendem o ocorrido. O enorme clarão no céu deixa todos em pânico diante do desaparecimento repentino dos seres humanos e animais. Tudo se dissipa e restam, a princípio, em localidade africana situada na interseção das nascentes dos rios Nilo, Congo e Zambeze, quatro personagens: o médico Simba Ukolo, que fora atender o chamado de um paciente em lugarejo próximo à sua cidade; D. Geny, religiosa fanática, pertencente aos Paladinos da Coroa Sagrada, religião relacionada com o mistério dos desaparecimentos ocorridos; a chorosa adolescente Jude; e Kiari, um homem que corria à procura de seu cão também sumido.

A surpresa de Simba Ukolo, médico e narrador principal da obra, aumenta na medida direta em que uma breve parada durante uma viagem entre Calpe e uma aldeia vizinha tornase a razão de sua sobrevivência ao grande clarão que resultou no apagamento colectivo de que não restou absolutamente nada. Em meio à desordem de carros e montes de roupa, únicos remanescentes dos desaparecidos, despontam personagens, como D. Geny, uma religiosa ultra-radical [...]. (DUTRA, 2009, p. 79).

Atmosfera trágica, surpreendente, apocalíptica domina a cena romanesca. Põe em questão a humanidade, levando os personagens a, filosoficamente, interrogarem-se: De onde viemos? Quem somos? Para onde vamos? Simba Ukolo e os demais sobreviventes tentam encontrar causas para a inesperada catástrofe, sem compreenderem que o clarão no céu fora provocado por uma explosão, alegoria que remete à crise social, econômica e ética do mundo contemporâneo, às voltas com inúmeros problemas, entre os quais: radicalismos religiosos, pobreza, fome, desigualdade, corrupção, em diversos países e regiões do planeta.

O mundo alegorizado no romance possui uma dupla face: mundo desenvolvido, que fecha as portas aos imigrantes, e mundo pós-colonial, com dificuldades econômicas objetivas 
de se reerguer. Mundo que exporta tecnologia e mundo que é palco de mão de obra barata e não raro, ainda hoje, se nutre da escravidão humana. Pepetela cria uma Calpe fictícia, póscolonial, para situar espacialmente a cidade africana, ao redor da qual se organizará a vida no planeta Terra, pois foi em seu entorno, ou em sua "faixa", que restaram os sobreviventes da arma letal, o "Feixe Alfa Gama", disparada da Europa por fanáticos da intolerância. (MIRANDA; FRIEDE; AVELAR, 2015, p. 121).

O quase fim do mundo começa distópico. Não há um tempo definido. O espaço é imaginário: Calpe, a cidade ficcional inventada por Pepetela, também presente em outras obras suas. O primeiro capítulo é narrado em primeira pessoa por Simba Ukolo, que toma consciência do desaparecimento das pessoas e animais de Calpe. A ordem e o governo findam; o mundo praticamente se acaba. Envolto em solidão e incredulidade, Ukolo pergunta-se como reorganizar a vida e reflete sobre os sentidos da palavra desaparecimento:

O fim do mundo não é tema que se trate com ligeireza, apesar de ter entrado em todas as línguas desde aquele primeiro dilúvio que tornou famoso Noé e sua arca. Também saiu constantemente das bocas de todos os trapaceiros que por este desgraçado planeta andaram, vendendo religiões de salvação ou poções para o evitar. O fim do mundo é assunto para ser tratado com delicadeza, prudência, reverente temor mesmo, pois implicou o óbito, ou melhor, o desaparecimento de quase todos os seres vivos. A palavra desaparecimento, espero sinceramente, está aqui colocada com toda a propriedade, foi pensada e repensada, sopesada até em balança hipersensível, antes de ser escrita. Se trata mesmo de desaparecimento, sumiço, eclipse, pois na realidade não sobrou nada deles, nem ossos nem cinzas, nem pêlos ou unhas, nada. Presumo que nem os espíritos se aproveitaram, tão rápido e global terá sido o apagamento colectivo. Mas voltemos ao relato de como me apercebi de estar sozinho na terra natal. (PEPETELA, 2008, p. 7-8).

Na citação, ficam evidentes momentos de reflexão de Simba Ukolo que não apenas relata acontecimentos. Também questiona a si e ao mundo. Contudo, não é o único a narrar. Cada capítulo é conduzido por um personagem ou pelo narrador onisciente. O romance, adotando um polifoco narracional, vai apresentando diferentes pontos de vista pertencentes a cada personagem. Há ocasiões em que, por intermédio de discursos 
indiretos livres, se superpõem os discursos do narrador onisciente e dos personagens, como se o primeiro penetrasse no fluxo dos pensamentos destes. Um clima de indecisão e insegurança afeta todos, havendo reiteradas interrogações e vasto campo semântico de dúvida. Os personagens indagamse: O que aconteceu? Pandemia? Guerra nuclear? Radicalismos religiosos? Como recomeçar?

Após o choque inicial com o sumiço de quase todos que habitavam Calpe, os sobreviventes esforçam-se para captar a dimensão da catástrofe. Para isso, além de Simba Ukolo e da religiosa Geny, Pepetela cria uma galeria de personagens emblemáticos formada por: uma historiadora somali chamada Ísis; por Jude, adolescente chorosa; por um louco que atendia por vários nomes; por Riek, kimbanda da Etiópia; por Janet, uma americana branca, pesquisadora da sexualidade dos chimpanzés; por Kiboro, ladrão de residências, espécie de Robin Hood; por Jan, misterioso mercenário sul-africano branco; por Nkunda, um menino sobrinho de Ukolo; e por um pescador anônimo. É por intermédio desses personagens, dos olhares trocados entre eles que diversos estereótipos em relação à África são questionados. O romance ressalta, criticamente, a ignorância do Ocidente em relação à diversidade de etnias, culturas, línguas, mitos e crenças existentes no continente africano.

Os sobreviventes, condicionados pelo capitalismo, procuram, em Calpe, um banco para sacar suas economias. Entretanto, não encontrando alimentos nem produtos à venda, compreendem que o dinheiro perdera o valor. Inicia-se, então, um processo de aprendizagem por meio de uma tournée que parte da África e chega à Europa. A rota traçada por Pepetela torna essa viagem uma contraviagem, pois o caminho trilhado pelos sobreviventes é inverso ao percorrido pelos antigos colonizadores. A direção tomada segue até Nairóbi; passa pelo Egito; caminha pelo "Vale dos Reis", "onde estão os túmulos dessa época fabulosa, em que um Estado africano era o mais poderoso e avançado do mundo" (idem, p. 302); depois, atravessa o Nilo rumo à antiga Tebas e a Karnak. Admirando a grandeza dos monumentos dessas civilizações africanas do outrora, é efetuada, a contrapelo, uma revisitação crítica da história da África. Por tal razão, a viagem prioriza o Egito, chegando apenas posteriormente a Roma, a Paris e à Alemanha, onde os 
sobreviventes constatam que o antigo luxo - casacos de pele, comida, joias - se deteriorara e o dinheiro perdera validade, tanto que diamantes deixados pelo sul-africano em um bar não possuíam mais serventia para eles.

Os personagens sobreviventes descobrem, ao final, que a explosão e o desaparecimento das vidas haviam sido provocados pelo «Feixe Gama Alfa», arma letal inventada para extermínio da humanidade pelos Paladinos da Coroa Sagrada, fanáticos religiosos e racistas, cujo "primeiro objetivo era impedir a imigração de gente dessas raças inferiores árabes, judeus, ciganos e africanos - para os países europeus" (idem, p. 340).

Das entrelinhas do discurso enunciador, emerge uma crítica mordaz ao plano de destruição do mundo planejado por esse grupo religioso radical, pois os poucos e únicos a sobreviver foram, justamente, os pertencentes a raças consideradas, preconceituosamente, inferiores e que, por ironia, viviam ou se encontravam na África.

A par da distopia dominante em quase todo o romance, laivos utópicos podem ser depreendidos quando alguns personagens questionam como construir uma nova humanidade. Há neles certa esperança, pois acreditam na capacidade de os humanos poderem reconstruir suas vidas, conforme assinala Ana Paula Tavares, no prefácio à edição brasileira de $O$ quase fim do mundo:

[...] a terra se rompe e o desaparecimento sucessivo da vida (homens, mulheres, insetos e outros bichos) acontece sem que uma razão clara (peste, guerra, furacão) tudo justifique. [...]

Devorados por um tempo que não é o deles os sobreviventes iniciam o ciclo das viagens onde como novos sujeitos da história descobrem os destinos e vão refundar o mundo. $\mathrm{O}$ continente africano resolve de novo o enigma da fundação: a partir de um centro renovar os ciclos, perceber o novo sentido da vida porque Calpe e o mundo à volta só conservam os mortos. A aventura começa e tudo se renova nesta narrativa misteriosa e fundadora. (TAVARES. In: PEPETELA, 2019, p. 7).

Ao procurarem um novo sentido para a vida, os sobreviventes parecem demonstrar inquietação não só com sua sobrevivência na África, mas com os rumos futuros da humanidade. O quase fim do mundo representa, assim, uma nova direção tomada pela ficção de Pepetela que se abre a reflexões 
e espaços mais amplos, ou seja, não apenas restritos a Angola e ao continente africano, conforme ocorre com grande parte de seus romances anteriores, como O desejo de Kianda (1995), que trazemos aqui para leitura por ser também uma narrativa distópica, na qual acontecimentos insólitos se sucedem em Luanda, capital angolana.

Tendo a ruína como imagem catalisadora, $O$ desejo de Kianda se tece por constantes desabamentos de edifícios, sem explicações plausíveis. O romance efetua, desse modo, uma caricatura alegórica de Angola independente, ingressante na economia de mercado, esquecida de muitos dos antigos sonhos libertários, e que se encontrava devastada por uma guerra fratricida desencadeada após as eleições presidenciais de 1992. O enredo desenvolve-se no ano de 1994, e o cenário é a cidade de Luanda, cheia de mutilados, carros importados, enfim, prenhe de contradições:

A rua tinha sido definitivamente fechada à circulação de veículos, por isso não se viam os carros dos novos ricos, últimos modelos de vidros fumados e ar condicionado, para proteger os passageiros dos pedidos constantes de esmola por parte dos meninos de rua, dos mutilados de todas as guerras, dos velhos atirados para a rua pela nova mendicidade. (PEPETELA, 1995a, p. 95).

O narrador, em terceira pessoa, por intermédio de intenso comprometimento político, consegue fazer profunda e lúcida análise do contexto social. Seu olhar assume a melancolia de quem narra de um lugar "dialeticamente dilacerado" (KONDER, 1988, p. 27), isto é, de quem vê se dissolverem os princípios ideológicos marxistas que sustentaram a luta de libertação de Angola. O narrador assume, então, a dissonância como forma de expressar seu mal-estar em relação ao status quo, ou seja, sua inadaptação ao presente e sua nostalgia pela perda de crenças e de valores do passado. Seu ponto de vista é

2 Segundo Leandro Konder (1988, p. 102), "a palavra melancolia vem do grego, de melanós (negro) e kholé (bílis). Designa um estado patológico do fígado que produz bílis escura e acarreta depressão, irritação". melancolérico, neologismo formado pela junção de "melancolia e cólera"'2 (idem, p. 102), amálgama revelador da indignação de quem não concorda com a realidade social na qual se encontra inscrito.

A ação romanesca principia com dois episódios quase simultâneos: o casamento dos personagens principais, Carmina Cara de Cu e João Evangelista, e o ruir inexplicável 
do primeiro prédio do Largo do Kinaxixe. Fecha-se, também, em círculo vicioso, com outro desabamento: o do edifício onde moravam os protagonistas. O texto de Pepetela instaura-se, dessa forma, como escrita catastrófica, implicando um agudo olhar de denúncia em relação à história do país. Sob a aparente ilogicidade das construções em ruína, o texto, figuradamente, alerta para a dissolução do Estado-Nação em Angola. É sintomático o primeiro prédio ter caído, justamente, na hora exata em que os noivos partiram para o banquete financiado com verbas públicas desviadas de fins sociais.

Carmina era membro destacado da Jota [...] Por estas razões a Jota investiu no casamento. Foram feitas requisições às empresas estatais [...] E a noiva ainda arranjou uma missão fictícia a Roma, paga evidentemente pelo Estado, para comprar o enxoval. (PEPETELA, 1995a, p. 12-13).

A descrição da festa das bodas expõe a derrocada dos valores éticos; o narrador, por meio de pequenos comentários irônicos, põe a nu mecanismos de corrupção presentes na sociedade angolana, chamando atenção para o uso indevido do dinheiro público por uma minoria que dele se aproveitava, enquanto a maioria do povo se tornava vítima da fome e da miséria.

Os constantes desmoronamentos pontuam o universo romanesco, funcionando como alegorias do fim do sonho libertário. As núpcias dos protagonistas representam a aliança de ideologias antes inconciliáveis. João Evangelista, o noivo, de origem protestante, encena a figura do acomodado, que aceita passivamente tudo para não se indispor e não perder os privilégios. Carmina, a noiva, ateia, de temperamento forte e combativo, mantém ligações com o governo, mas, embora tenha sido militante do Partido, como muitos companheiros, se beneficia, agora, do poder, esquecida dos princípios que sustentaram a luta política da independência.

- Vamos enriquecer [...]. Quer dizer, o Governo legitimamente eleito não pode legalmente se armar [...] Mas há uma maneira de se resolver a questão. Certas empresas que não são do Governo dão o nome[...] Claro que a empresa que dá o nome ganha uma comissão, uma pequena percentagem porque é para um fim patriótico. Só que uma pequena percentagem num negócio de muitos milhões é muitas centenas de miles 
de dólares. [...] Fui contratada porque, bolas, já que há negócio, que seja para camaradas que sempre foram firmes, por que razão dar a outros? (idem, p. 57-58).

Os únicos personagens não coniventes com esse universo de degradante corrupção são: "o mais velho Mateus", crítico das fraudes na vida política do país; o velho cego Kalumbo; a menina Cassandra, cuja inocência a levava a ouvir o desejo de Kianda.

Kianda se sentia abafar, com todo aquele peso em cima, não conseguia nadar, e finalmente se revoltou. E cantou, cantou, até que os prédios caíssem todos, um a um, devagarinho, esse era o desejo de Kianda. E foi isso que Cassandra contou a mais velho Kalumbo. (idem, p. 109).

Representantes da tradição africana, os velhos, por serem guardiães do saber ancestral, e a criança, por apresentar um olhar ainda não contaminado pelos vícios do presente social, são valorizados na narrativa, sendo os que oferecem ainda alguma resistência, embora fique claro no texto que não são ouvidos pela sociedade angolana em crise. O desmoronar dos prédios pode, segundo nossa interpretação, alegorizar o próprio ruir da tradição oral, a interdição de discursos proféticos, o que assinala, naquele contexto social e político de Angola, o caráter apocalíptico das utopias.

Um milagre vinha mesmo a calhar para essa época de pouca crença, em que o governo se dizia marxista, embora muitos suspeitassem não passar de propaganda. A tese do milagre ganhou portanto num ápice adeptos incondicionais, especialmente concentrados nas igrejas de Luanda, quer nas tradicionais, europeias, americanas ou africanas, quer nas novas seitas electrónicas. (idem, p. 11).

Os vazios utópicos são, geralmente, propícios à proliferação não só de fundamentalismos religiosos, mas também à formação do individualismo que visa à acumulação de bens, passando por cima dos antigos valores éticos defendidos pelo socialismo. Em entrevista sobre o livro, Pepetela (1995b, p. 15) faz o seguinte comentário: “O capitalismo instalou-se nas consciências e as pessoas contam consigo próprias e lutam pela vida passando por cima umas das outras, negociam, fazem esquemas. A única moral é ganhar dinheiro rápido". 
A construção romanesca encontrada por Pepetela expressa a revolta e a sensação de avaria que define o contexto social de seu país no momento histórico por ele focalizado. Em contraponto ao discurso cético do narrador e à desesperança dos diálogos travados pelos personagens, emerge, em itálico, como prenúncio da ruína que se abate sobre Luanda, o canto mágico de Kianda, alegorizando a identidade perdida, a impossibilidade de retorno às origens no presente.

Em Angola, o mito de Kyàndà, Kítùtà ou Kíxímbì pertence ao imaginário quimbundo e tem suas origens em épocas remotas. De acordo com Ruy Duarte de Carvalho (1989, p. 283287) e Virgílio Coelho (1997, p. 127-191), o culto às ianda (plural de Kianda, divindade do mar) sempre existiu secretamente, mesmo após a colonização, sendo uma prova de resistência do imaginário mítico africano. As ianda são entidades reguladoras de tudo que se relaciona ao oceano. Regem as marés, as vagas, os peixes, a pesca. Gostam de ser homenageadas. Por isso, pescadores lhes fazem oferendas, geralmente um banquete anual em praias afastadas da Ilha de Luanda.

No romance de Pepetela, Kianda é alegoricamente veiculada pelo discurso ficcional. $\mathrm{O}$ animismo africano invade a narrativa, e o grito rebelde da deusa ressoa na dimensão mítica e literária. Luandino Vieira e Arnaldo Santos, escritores da vida real e conhecedores das tradições luandenses, são apropriados pelo texto de Pepetela e tornam-se personagens que dialogam com João Evangelista. Representam o contraponto da resistência literária em diálogo fecundo com o imaginário mítico angolano, na defesa da identidade angolana em crise que o canto de Kianda expressa:

Ouviu a estória um dia, ali mesmo numa esplanada do Kinaxixe, quando se sentou com o maior respeito à mesa onde se encontravam dois escritores, Luandino Vieira e Arnaldo Santos, grandes sabedores das coisas de Luanda. Como não podia deixar de ser, os kotas falavam da sua meninice kinaxixense, embora Luandino fosse do Maculusso, que de fato era ali ao lado. E foi ele mesmo que contou, lembras, Arnaldo, quando a mafumeira chorou sangue durante sete dias, não se sabe se de dor de ser cortada se de pesar por tirarem a lagoa à Kianda? (PEPETELA, 1995a, p.47, grifos nossos)

Na tradição angolana, a lagoa de Kianda era chamada em quimbundo dizanga dia muenhu, cujo significado era "lagoa 
da vida", fonte de força criadora e reservatório de mitos primordiais. No romance de Pepetela, em vez de remeter à fecundidade, à energia vital, a lagoa, sob as ruínas dos edifícios caídos, torna-se lodosa, representando a putrefação social, a morte e a asfixia do tecido mítico. É um dos sinais da "síndrome de Luanda" que revela o esgarçamento das utopias culturais e políticas na Angola dos anos 1990 e sinaliza a ruptura dos elos com a ordem cósmica reguladora das tradições do imaginário popular angolano.

O final do romance, em aberto, com a imagem de Kianda, livre, fugindo para alto mar, aponta, ambiguamente, para o esfacelamento das utopias, entretanto, acena, também, para uma trilha talvez possível: a do universo mítico-literário, espaço de reflexão crítica e de denúncia das corrupções que afogam o país. A fuga de Kianda configura, assim, não só a impossibilidade dos antigos ideais socialistas, mas se constitui, ainda, como alegoria de uma perspectiva de indignação e mudança que fica ecoando no ar.

Assemelhando-se a essa obra de Pepetela pela ambiência insólita e distópica, o filme Ar condicionado (Figura 1) - longametragem recém-lançado em 2020, realização de Fradique Bastos, produção de Jorge Cohen, fotografia de Ery Claver, jovens angolanos membros da Geração 80 - vem impactando o cenário do cinema em Angola e, igualmente, o de festivais internacionais para os quais foi selecionado, como o de Roterdão, na Holanda, e outros, na Suíça, Arábia Saudita, China, Polônia, Austrália e Áustria.

Vinte e cinco anos separam O desejo de Kianda (1995) de Ar condicionado (2020). Tanto a narrativa romanesca como a cinematográfica efetuam críticas, respectivamente, às classes sociais de Angola das décadas 1990 e 2020, ambas aludindo ao mito de Kianda, que, simultaneamente, remete às tradições luandenses e aos resíduos de esperança resistentes às distopias do presente.

Lembrando o ruir misterioso dos prédios do romance de Pepetela, aparelhos de ar-condicionado, enigmaticamente, também despencam das janelas de edifícios de Luanda, na narrativa fílmica, cujos personagens principais são: o guarda Matacedo sem audição em decorrência da guerra; Zezinha, faxineira doméstica, que, da janela, contempla perplexa os 


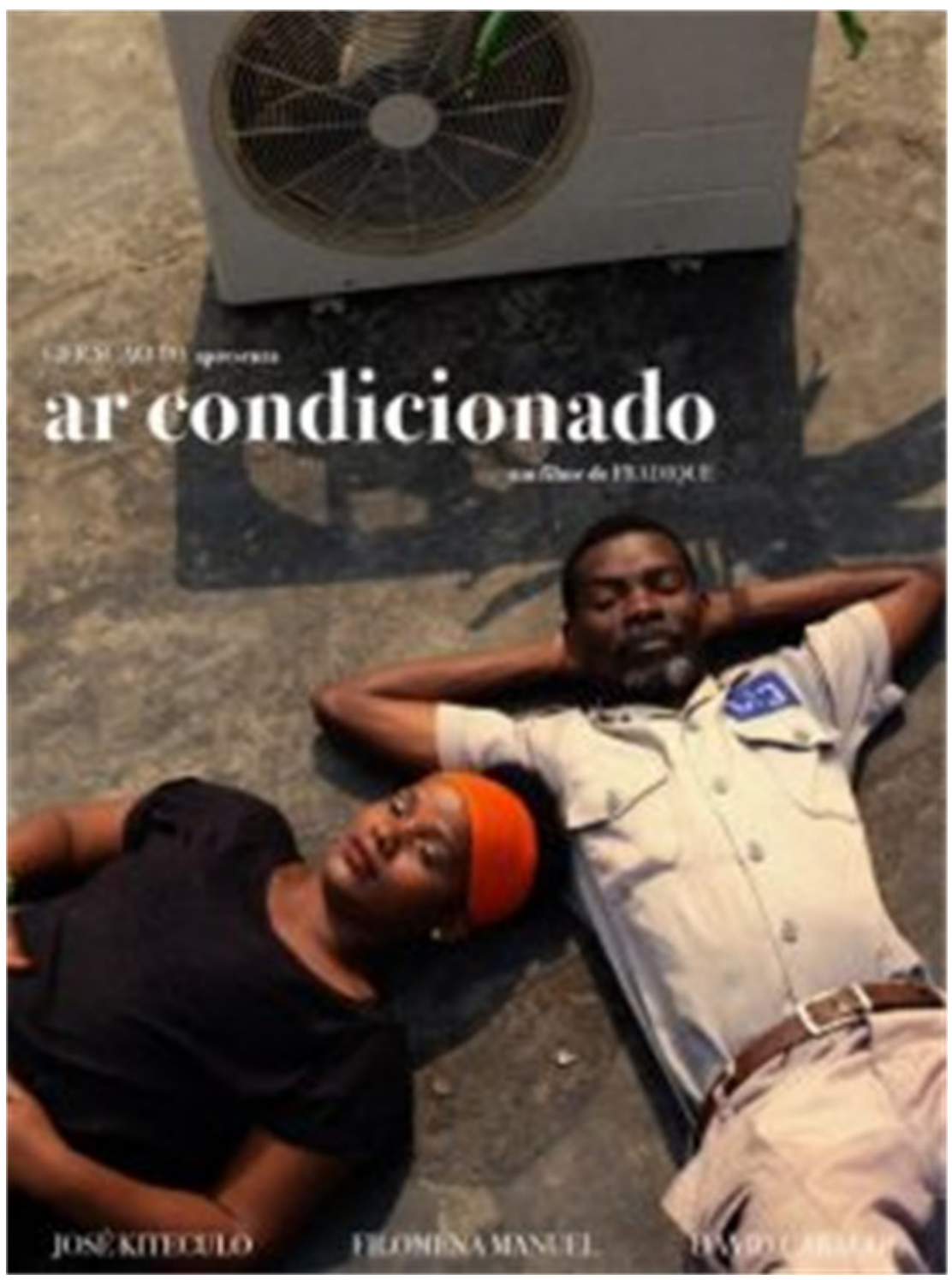

Figura 1 - Capa do DVD do filme Ar condicionado

Fonte: filme Ar condicionado, realização de Fradique Bastos, produção de Jorge Cohen, fotografia de Ery Claver, Produtora Geração 80.

misteriosos acontecimentos (Figura 2); Kota Mino, senhor de idade responsável pelo conserto de equipamentos elétricos em loja antiga da Baixa. Os dois primeiros, encarregados de reaver o ar-condicionado do chefe, dirigiram-se ao estabelecimento comercial de Mino (Figura 3), cujo ofício secreto consistia em inventar complexa máquina de recobrar memórias. Segundo esse personagem, os aparelhos caíam, pois absorviam o peso 


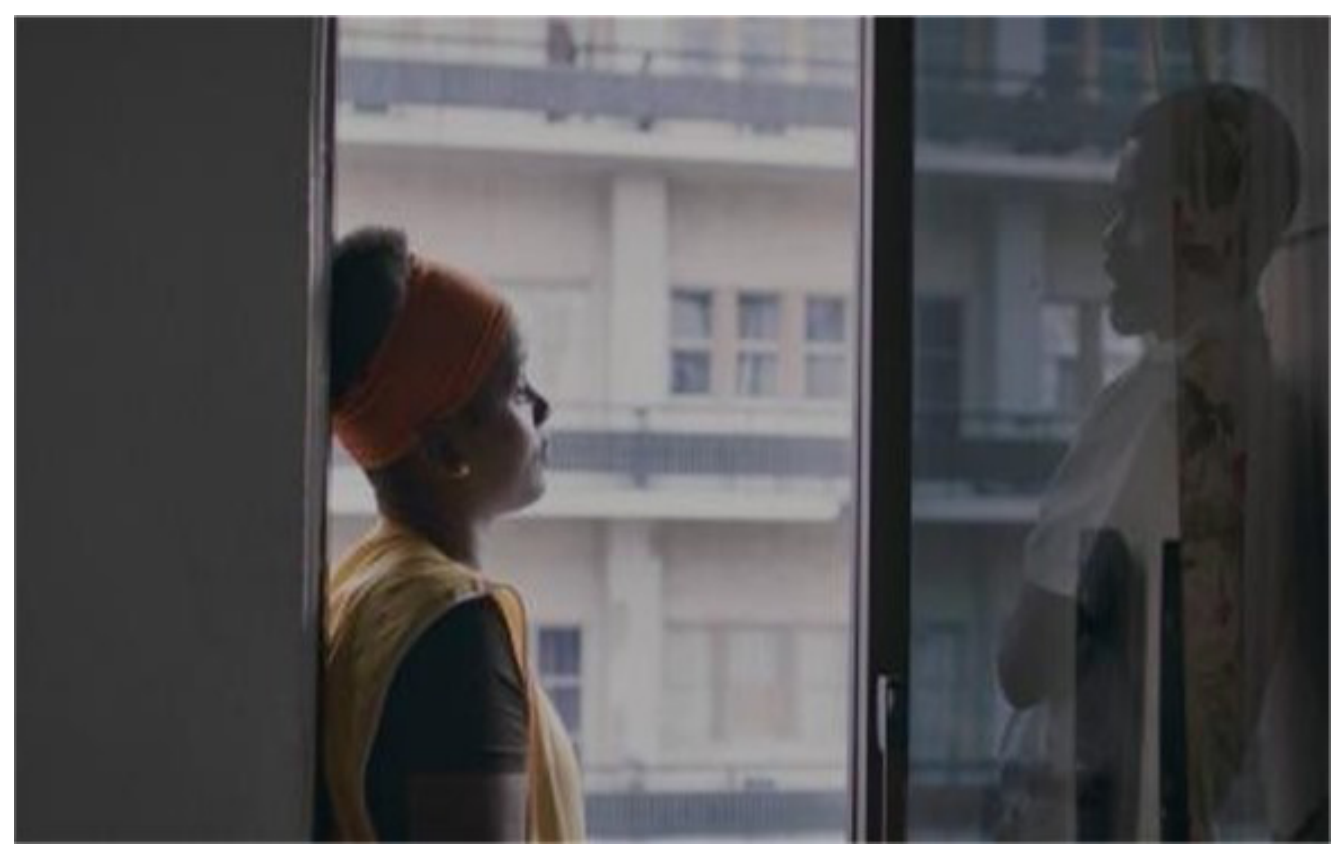

Figura 2 - Zezinha e a contemplação da enigmática queda dos aparelhos de arcondicionado em Luanda.

Fonte: filme Ar condicionado (1:07':04"), realização de Fradique Bastos, produção de Jorge Cohen, fotografia de Ery Claver, Produtora Geração 80.

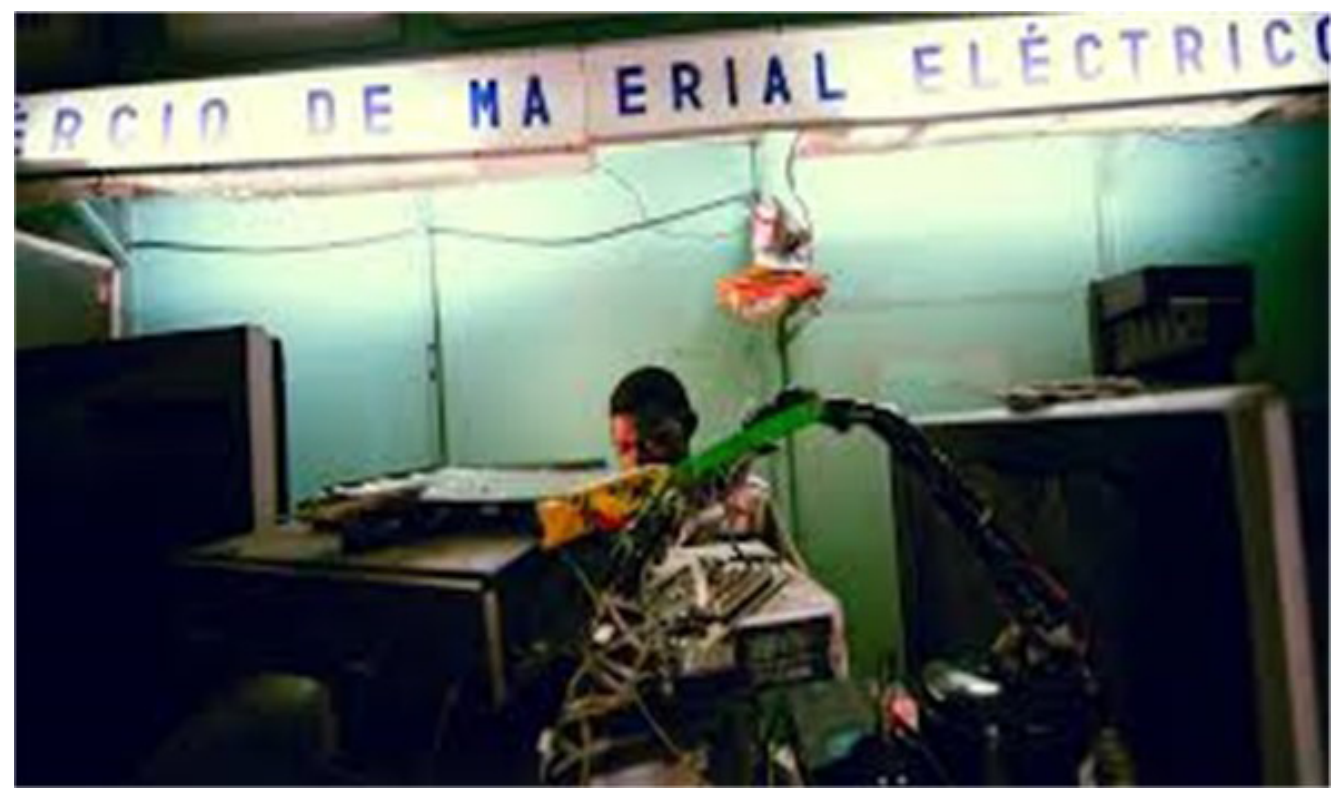

Figura 3 - A loja de Kota Mino no centro de Luanda. (Em entrevista, o produtor Jorge Cohen informou que esse estabelecimento comercial ainda existe no mesmo local.)

Fonte: filme Ar condicionado (35':29"), realização de Fradique Bastos, produção de Jorge Cohen, fotografia de Ery Claver, Produtora Geração 80. 
das memórias do passado, a carga das guerras que esgarçaram lembranças, causaram mortes e solidão.

O filme apreende a atual atmosfera de Luanda, cidade cheia de desigualdades, com excessivo barulho de carros e arranha-céus invisibilizando velhas edificações do tempo colonial. Apesar da paz proclamada em 2002, o medo continuava a percorrer casas da elite e das classes mais aquinhoadas, em cujas portas havia sempre um segurança, em geral, um ex-combatente, portador de sequelas, como Matacedo, que ensurdecera e se tornara apático, um morto-vivo, trazendo na própria onomástica a ideia de morte prematura tão comum durante os longos anos de guerra em Angola.

A abertura do filme, de modo bastante original, apresenta os diversos significados das palavras: ar ("fluido que envolve a terra"; "espaço aéreo"; "fluido que respiramos"; "vento, aragem"; "aparência, aspecto"; "modo"); condicionado ("condicionar, tornar dependente de uma condição"; "pôr condições a"; "acondicionar"); ar-condicionado (substantivo composto que designa aparelho refrigerador de ambientes).

Tal preocupação semântica e o título Ar condicionado sem hífen - dão margem a várias interpretações, instaurando enriquecedora polissemia cinematográfica, que tanto abrange questões culturais e políticas, como percepções poéticas em relação à vida e à existência.

Após a tela de abertura, a câmera vai focalizando várias paisagens de Luanda e detém-se em alguns outdoors com fotos de personalidades importantes da Revolução angolana, entre as quais a de Manguxi, como era carinhosamente denominado Agostinho Neto, primeiro presidente de Angola. A música intensa, impactante, e as imagens dos líderes revolucionários do passado integram o espaço da cidade, lembrando os ideais políticos dos anos 1960-1970.

Cortes inesperados trazem ao écran outros locais e ângulos da cidade. Há um espanto no ar com a queda enigmática de aparelhos de refrigeração. Tudo desaba em Luanda. Ar condicionado funciona como uma alegoria da "modernidade líquida", conceito cunhado pelo filósofo polonês Bauman (2000), quando se refere ao mundo atual globalizado, no qual relações sociais, econômicas e de produção se tornam frágeis, fugazes, escorregadias, fluindo como líquidos. "Tudo que é sólido desmancha no ar" (BERMAN, 1986, p. 23). Das 
entrelinhas do filme, emergem incertezas que também atingem os espectadores: os sonhos libertários de Angola, defendidos pelos líderes celebrados nos outdoors, também desmoronavam?!...

São várias as Luandas representadas no filme: a do guarda Matacedo e a de Zezinha; a do chefe deles; a do Kota Mino; a das crianças que jogavam bola, cujos vultos projetados na parede pareciam teatro de sombras; a do passado do pai de Zezinha, quando era pescador na Ilha; a das melodias que se cruzam pela narrativa fílmica, como, por exemplo, a do hino nacional angolano a relembrar - para quem conhece sua letra - slogans da luta de libertação: "Angola unida, Revolução!"; "Pelo poder popular!"; “Um só povo, uma só nação!” (Ar condicionado, 2020, 46':38"-48':01"). Tais versos contrastam com os desabamentos e, diante do caos, indagações pairam no ar: onde a nação, o povo unido, o poder popular?

A câmera vai captando o complexo cotidiano de Luanda. Focaliza o komba, ritual de óbito de uma vizinha de Zezinha, no qual mulheres choravam em coro um pranto não apenas pela morte de $\mathrm{D}$. Ana, porém pelas inúmeras perdas recentemente sofridas por Angola. Enfoca, a seguir, uma cena de meninos limpando e engraxando sapatos no terraço de um prédio, ao mesmo tempo que entoavam um rap, cuja letra crítica reivindicava oxigênio, ar puro para aspirar, recusando o consumismo, os condicionamentos sociais, tal como Achille Mbembe propõe, indignando-se:

[...] contra tudo o que condena a grande maioria da humanidade à paragem prematura de respiração, tudo o que ataca fundamentalmente as vias respiratórias, tudo o que, na longa duração do capitalismo, confinou segmentos inteiros de populações e raças inteiras a uma respiração difícil, ofegante, a uma vida pesada. Mas para daí sair é preciso ainda compreender a respiração, para lá de aspectos puramente biológicos, como aquilo que nos é comum e que, por definição, escapa a qualquer cálculo. Falamos, assim, de um direito universal de respiração.[...] É preciso então compreendê-lo como um direito fundamental à existência. (MBEMBE, 2020, s. p.)

Zezinha também almejava essa liberdade de respirar, quando recordava sua infância na Ilha com o pai pescador que 
sabia olhar o mar, esperar a brisa fresca da manhã, conhecendo a temperatura certa do oceano e os ventos de Kianda.

O fio condutor do filme se tece pela recorrente oposição entre o ar condicionado, pesado e viciado da cidade, versus o ar livre, leve e límpido da natureza. Não há linearidade na narrativa fílmica que, desalinhadamente, flui entre cortes inesperados e memórias afetivas, entre luzes e sombras de corredores labirínticos e escuros de antigos edifícios em ruína situados na Baixa de Luanda. Há, no tratamento do tema e na caracterização dos personagens, intensa subjetividade estética e política por parte do realizador, do fotógrafo, da composição das músicas, tornando o filme aberto, na linha do que se denomina cinema de autor.

[...] é preciso parar para ouvir [...], sentir a intensidade impressa num jogo de luz e sombra composto entre o preto e o branco, conectar-se com uma lentidão quase sonífera, conhecer o cinema de autor. Toda uma atmosfera precisa ser cavada para dar lugar ao cinema e seu tempo intensivo. (FARINA; FONSECA, 2015, p. 118) .

A referida subjetividade estética e política processa-se no discurso fílmico por intermédio de jogo artístico que vai entrelaçando perfis dos personagens, imagens da cidade e trilha sonora, sempre em interação com a temática e o enredo do filme. Há um tratamento pessoal, subjetivo por parte do realizador e do fotógrafo na apreensão dos cenários e comportamentos dos personagens, por meio de diálogos e recursos cinematográficos como planos longos e fechados, estes utilizados quando a câmera adentra o mundo interior dos protagonistas, captando-lhes pensamentos, lembranças e imaginações.

Ar condicionado, em diversas passagens, opera com "imagens-tempo" (DELEUZE, 2009, p. 55-105), ou seja, imagens que penetram a interioridade, a emotividade dos personagens, repotencializando cenas cotidianas da vida, de modo que essas fiquem mais visíveis pelas lentes da câmera. De acordo com Deleuze, "toda subjetividade é o tempo, o tempo não cronológico" (idem, p. 103); e, segundo o filósofo, nunca é apenas individual, pois cada sujeito traz também em si memórias da história social por ele vivenciadas. No caso do filme, a subjetividade é política e estética, na medida em que 
transporta, artística e criticamente reinventados para a tela, sonhos, mitos, memórias e fantasmas individuais e coletivos que vagueiam pelos pensamentos e imaginários não somente do realizador, mas também dos personagens e da sociedade angolana representada pela película em questão.

Para Gilles Deleuze, há dois tipos de cinema: o clássico e o moderno. No primeiro, há o predomínio da ação; a montagem segue uma lógica de causa e efeito, concatenando as imagens por meio de uma linearidade narrativa que se direciona para a resolução dos conflitos. Esse tipo de cinema é designado por Deleuze como "imagem-movimento" (DELEUZE, 1985, p. 93-108), distinguindo-se por apresentar um esquema sensóriomotor que trabalha com enredos e mensagens, até certo ponto, previsíveis. Já o cinema moderno atua com a "imagem-tempo", rompendo com conexões sensório-motoras esperadas e com ações sucessivas e sequenciadas. Essa segunda forma de cinema explora o espaço-tempo, não se preocupando com a narrativa em si, mas com uma constante produção crítica de pensamentos e emoções. Nessa modalidade de cinema, não ocorre um encadeamento linear de imagens: “Em vez de uma imagem depois da outra, há uma imagem mais outra e cada plano é desenquadrado em relação ao enquadramento do plano seguinte" (DELEUZE, 2007, p. 255). A "imagemtempo" não trabalha com um tempo métrico, porém com temporalidades diversas, muitas vezes superpostas, em que a subjetividade dos personagens vem à tona enquanto memória, sentimento, reflexão. No cinema-tempo, imagens-lembrança e imagens-sonho transitam, sem uma hierarquia cronológica, do presente para o passado e vice-versa. É o que ocorre no filme Ar condicionado.

Zezinha recorda sua infância na Ilha e as fantasias do pai; Kota Mino grava memórias antigas do outrora: o ontem e o hoje se entrançam. Dessa forma, a narrativa fílmica "dilata o sentido do tempo e transforma os sentidos das

${ }^{3}$ FRAZÃO, Aline. "Ar Condicionado estreia online amanhã". In: Blog Aline Frazão. Luanda, 05 de junho de 2020. Disponível em: <http://www. alinefrazao.com/ caderno/tag/

banda+sonora $>$ Acesso em: 25 ago. 2020. coisas", conforme declara em seu blog ${ }^{3}$ Aline Frazão, cantora e compositora angolana, autora da trilha sonora (Figura 4) criada especialmente para esse longa-metragem.

Cinema-poesia - assim podemos classificar a escrita cinematográfica de Fradique, pois, o tempo todo, os dramas apreendidos e ficcionalizados no écran são perpassados por olhar e dicção carregados de sentimento, imaginação, 


\section{RELEASE | LANÇAMENTO 02.10 .2020}

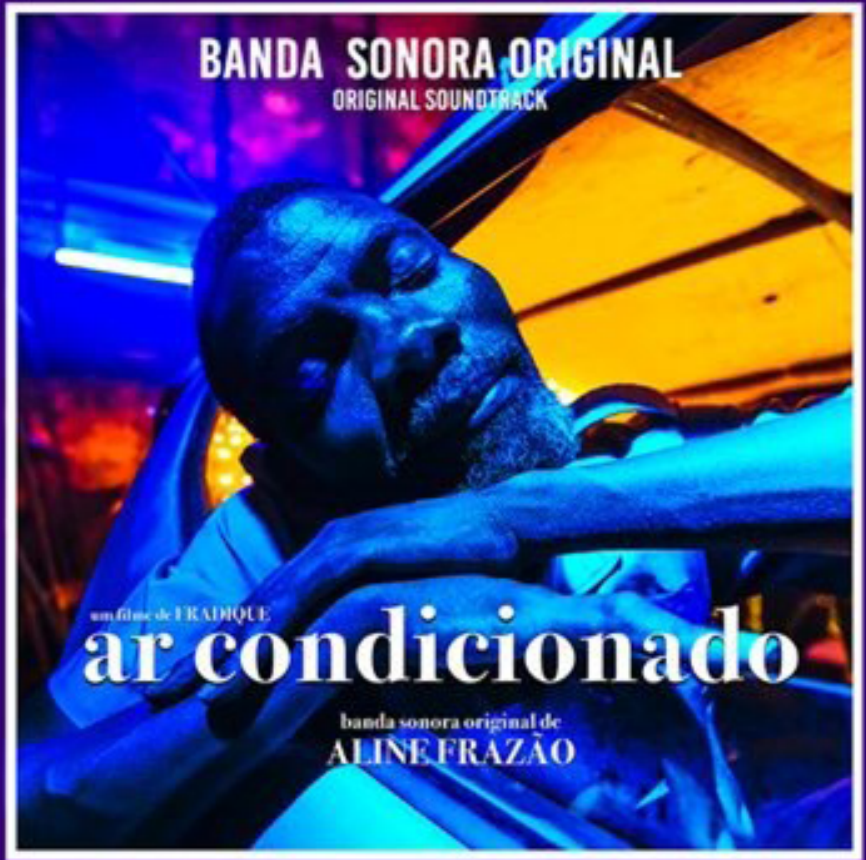

Espotify ćm MUSIC amazonmüsic $\gg$ Google Play

\section{WHDEZZR * TIDAL}

Figura 4 - Capa do CD da banda sonora composta por Aline Frazão especialmente para o filme Ar condicionado, de Fradique Bastos. (A imagem da capa do CD é a mesma do poster oficial do filme.)

Fonte: Poster oficial do filme elaborado pela Produtora Geração 80, fotografia de Ery Claver.

consciência e lucidez, capazes de transfigurar a realidade representada. Imagens em movimento, iluminação, planos longos, diálogos, planos fechados, closes dos personagens contracenam com a letra e a melodia da canção "Matacedo", de Aline Frazão, em que "instrumentos de sopro potentes [... ] aspiram ar para devolver poesia" (POLACOW, 2020), construindo, desse modo, a performance poética da filmografia.

A música, obviamente, não é mera ilustração. Ao contrário, faz parte da narrativa e do espaço fílmico. "Sem som, não há memória" - advertia Kota Mino, absorto a inventar a 
intrincada máquina de lembranças, por intermédio da qual urdia memórias de solidões e as gravava em fita cassete que, no filme, se erige como alegoria da necessidade urgente de preservação da imaginação criadora, dos sonhos de outrora, das tradições e da história de Angola.

A letra da música "Matacedo" sonha um país novo e recorda um tempo em que tudo era considerado melhor. Nesse sentido, compactua não só com Kota Mino, mas também com a mensagem do filme que ressalta, criticamente, o quanto Luanda e seus habitantes, em razão do consumismo desenfreado, com prédios altos e espelhados a ocultarem as construções antigas da cidade, estão a perder em termos de relações humanas e de sua própria história:

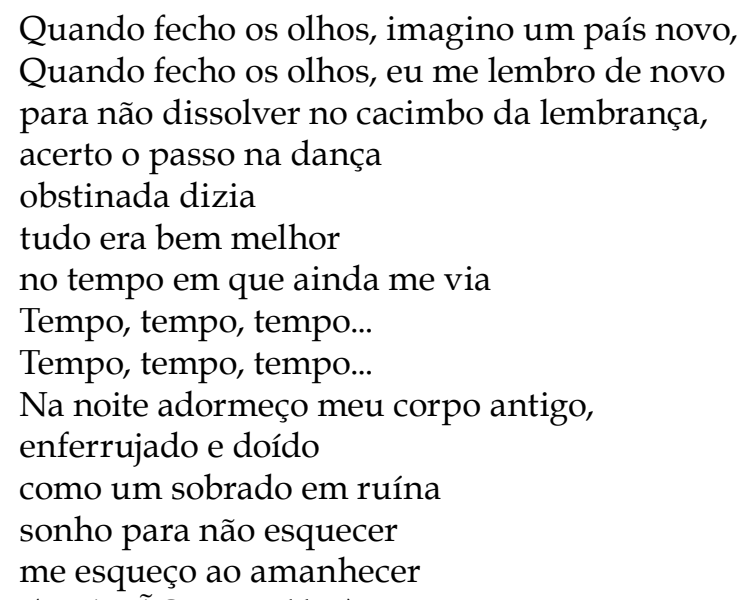
(FRAZÃO, 2020, blog,

Ar condicionado, apesar do cenário onírico e distópico, deixa, ao final, em suspenso, um tom até certo ponto esperançoso, sugerindo a retrotopia que consiste no regresso ao passado, sinalizando a reinvenção de antigas memórias e a possibilidade destas poderem recuperar os ventos do mar, $\mathrm{o}$ ar livre da Kianda, a capacidade de sonhar e criar.

Embora os romances e filmes abordados neste ensaio tenham em comum esse viés de esperança, as perspectivas distópicas assumem, em cada obra analisada, formas e facetas críticas diferentes. Os textos de Pepetela adotam um tom melancolérico, irônico, bastante mordaz e satírico. Em O quase fim do mundo, o olhar distópico direciona-se a um cenário mais alargado, que não se restringe à África, voltando-se para o mundo em geral. Questiona racismos xenófobos e fanatismos 
religiosos que, preconceituosamente, discriminam imigrantes e refugiados, principalmente na Europa. Nesse romance, a indignação e a ironia se revelam mais cáusticas, ferinas e pungentes, denunciando o aumento das incertezas humanas em âmbito mundial.

Em O desejo de Kianda, o olhar crítico do narrador se dirige a Angola pós-independente, colocando em questão o declínio dos ideais e valores revolucionários que começavam a ser substituídos por condutas consumistas. A ironia, o insólito e a ruína recursivos na narrativa expressam, de modo alegórico, o ruir dos antigos sonhos libertários em Angola.

No filme Ar condicionado, os desabamentos dos refrigeradores, sem explicação lógica, assinalam, igualmente, a presença da ruína e do insólito. Contudo, o contexto social angolano focalizado não é mais, como em $O$ desejo de Kianda, a Luanda da década de 1990; é a cidade vinte anos depois, em pleno século XXI, com traumas, sequelas - entre os quais, por exemplo, a surdez e a apatia de Matacedo, a falência da memória - e fantasmas a assombrar o presente confuso, perpassado por várias temporalidades. Uma atmosfera onírica e sombria envolve Luanda que, melancólica e metonimicamente, também representa o país. A alegoria da máquina da memória inventada por Kota Mino, entretanto, ao recuperar e gravar fantasias e histórias do passado, traz deste lembranças e fragmentos líricos, os quais, talvez, possam amenizar o clima tenso e pesado que paira sobre a cidade.

Tanto nos romances de Pepetela, como em Ar condicionado, constatamos que as distopias, literária ou cinematograficamente expressas, incitam reflexões. Romances e filmes distópicos podem, destarte, soar como alarme, ou seja, como alerta a perigos presentes ou vindouros. Embora apontem para efeitos destruidores de catástrofes, por vezes, interseccionam-se com resquícios de pensamentos utópicos, deixando entrever, em seus desfechos, vestígios esgarçados de esperança.

Chegamos, assim, à conclusão de que diversas narrativas distópicas, frequentes na ficção contemporânea, seja na literatura, seja no cinema, não se limitam a denúncias funestas e melancólicas em relação ao mundo atual, realizando, concomitantemente, um trabalho estético e político de crítica e resistência. 


\section{REFERÊNCIAS}

AGUALUSA, José Eduardo. Os vivos e os outros. Lisboa: Quetzal, 2020.

AR, Condicionado. Direção: Fradique (Mário Bastos). Produção: Jorge Cohen. Luanda: Produtora Geração 80, 2020, longametragem (72 min.) exibido em plataforma on line première: https://bit.ly/2ZEsd50, vídeo privado disponibilizado pelos realizadores, apenas, na estreia (em 06/06/2020) e por mais sete dias. Acesso em: 12/06/2020.

BAUMAN, Zygmunt. Modernidade líquida. Trad. de Plínio Dentzien. Rio de Janeiro: Jorge Zahar Ed., 2000.

BAUMAN, Zygmunt. Retrotopia. Trad. de Renato Aguiar. Rio de Janeiro: Zahar, 2017.

BENTIVOGLIO, Júlio; CUNHA, Marcelo Durão R. da; BRITO, Thiago Vieira de (org.). Distopia, literatura E história. Serra: Ed. Milfontes, 2017.

BERMAN, Marshal. Tudo que é sólido desmancha no ar: a aventura da modernidade. Trad. de Carlos Felipe Moisés e Ana Maria Ioriatti. São Paulo: Companhia de Letras, 1986.

BOOKER, M. Keith. The dystopian impulse in modern literature: fiction as social criticism. Westport, Conn. London: Greenwood Press, 1994.

CARVALHO, Ruy Duarte. Ana a Manda: os filhos da rede. Lisboa: Instituto de Investigação Científica Tropical, 1989. p. 284-285.

COELHO, Virgílio. Imagens, Símbolos e Representações.“Quiandas, Quitutas, Sereias!”: imaginários locais, identidades regionais e alteridades. Reflexões sobre o quotidiano urbano luandense na publicidade e no universo do marketing. Ngola, Revista de Estudos Sociais, Luanda, v. 1, n. 1, p. 127-191, janeiro-dezembro, 1997.

DELEUZE, Gilles. Cinema 1: a imagem-movimento. Trad. Stella Senra. São Paulo: Brasiliense, 1985. 
DELEUZE, Gilles. Cinema 2: a imagem-tempo. Trad. Eloísa Araújo Ribeiro. 4a. ed. São Paulo: Brasiliense, 2009.

DELEUZE, Gilles; GUATTARI, Félix. O que é a filosofia? Trad. Bento Prado Jr. e Alberto A. Muñoz. São Paulo: Editora 34, 2007.

DUTRA, Robson. Resenha de O quase fim do mundo (2008), de Pepetela. O Marrare, Revista da Pós-Graduação em Literatura Portuguesa/ UERJ, Rio de Janeiro, n.10, p. 79-82, 2009. Disponível em: www.omarrare.uerj.br/numero10/resenha. html. Acesso: 03 out. 2020.

FARINA, Juliane Tagliari; FONSECA, Tania Mara Galli. O cine-pensamento de Deleuze: contribuições a uma concepção estético-política da subjetividade. Scielo: Psicologia USP, São Paulo, v. 26, n.1, p.118-124, jan.-jun., 2015. Disponível em: www. scielo.br/pusp Acesso em: 15 ago. 2019.

FRAZÃO, Aline. "Ar Condicionado estreia online amanhã". In: Blog Aline Frazão. Luanda, 05 de junho de 2020. Disponível em: http://www.alinefrazao.com/caderno/tag/banda+sonora Acesso em: 25 ago. 2020.

KONDER, Leandro. Walter Benjamin: o marxismo da melancolia. Rio de Janeiro: Ed. Campus, 1988.

KOPENAWA, Davi; ALBERT, Bruce. A queda do céu: palavras de um xamã yanomani. Trad. Beatriz Perrone-Moisés. $7^{\mathrm{a}}$. impressão. São Paulo: Companhia das Letras, 2015.

MBEMBE, Achille. O direito universal à respiração (Texto originalmente publicado em francês, em 05/04/2020, em https://aoc.media/opinion/2020/04/05/le-droit-universela-la-respiration/). Trad. Ricardo Moura. Disponível em: https://medium.com/textura/o-direito-universal-\%C3\%A0respira\%C3\%A7\%C3\%A3o-8929b9882d20. Acesso em: 11 abr. 2020.

MIRANDA, M. Geralda; FRIEDE, Reis; AVELAR, Katia. A Dualidade Alegórica da Catástrofe em O Quase Fim do Mundo, do escritor angolano Pepetela. Abril, Revista do Núcleo de Estudos de Literatura Portuguesa e Africana da UFF, Niterói. 7, n. 14, p. 119-127, $1^{\circ}$ sem., abril, 2015. Disponível em: https:// 
periodicos.uff.br/revistaabril/article/view/29854. Acesso em 22 dez. 2020.

PEPETELA. O desejo de Kianda. Lisboa: Dom Quixote, 1995a.

PEPETELA. "Da utopia à amargura", entrevista concedida a Rodrigues da Silva. In: JL- Jornal de Letras, Artes E Ideias. Lisboa, n.638, p.14-16, 29 março 1995b.

PEPETELA. O quase fim do mundo. Lisboa: Dom Quixote, 2008. POLACOW, Fernanda. O ar em suspenso, sobre o filme 'Ar condicionado'. Buala, Lisboa, em 17 de agosto de 2020. Disponível em: https://www.buala.org/pt/afroscreen/o-ar-em-suspensosobre-o-filme-ar-condicionado. Acesso em 25 ago. 2020.

TAVARES, Ana Paula. Velho mundo, mundo novo (prefácio). In: PEPETELA. O quase fim do mundo. São Paulo: Editora Kapulana, 2019. p. 7. 


\section{ABSTRACT}

Apocalypses and Catastrophes: The Place of Dystopia in Contemporary Narratives of Angolan Literature and Cinema

The article aims to reflect on temporalities and dystopic times present in contemporary narratives of Angola, in both literature and cinema. Based on the novels $O$ desejo de Kianda (1995) and O quase fim do mundo (2008), by Pepetela, and in the film Ar condicionado (2020), by the filmmaker Fradique (Mário Bastos) and the producer Jorge Cohen, it is intended to carry out a survey of allegorical representations, investigating and discussing their respective meanings and the place of criticism and resistance in narratives considered dystopian.

Keywords: Angola. Literature. Cinema. Dystopia. Resistance.

Carmen Lucia Tindó Secco é Professora Titular de Literaturas Africanas de Língua Portuguesa da UFRJ. É Doutora em Letras pela UFRJ. Realizou Pós-Doutorado na UFF e na U. A. Politécnica de Moçambique. Pesquisa e orienta na área das Literaturas Africanas e outras artes. Projetos atuais: "Cinegrafias de Angola, Cabo Verde e Guiné-Bissau: Literatura, História e Afeto" e "Poesia Africana dos séculos XX e XXI", desenvolvidos no Programa de Pósgraduação em Letras (Letras Vernáculas) da Faculdade de Letras da UFRJ (CAPESPrint), CNPq e FAPERJ. 